\title{
室内気流分布を考慮した通風性能評価に関する研究 室内通風デグリアワーを用いた戸建住宅の通風性能評価
STUDY ON THE EVALUATION OF CROSS VENTILATION PERFORMANCE CONSIDERING DISTRIBUTION OF INDOOR AIRFLOW VELOCITY
Evaluation of cross ventilation performance of the detached house with cross ventilation degree hours of inside area

\author{
赤林伸一*1, 坂口 淳*2, 細野淳 美*3, 佐 藤英 樹*4 ${ }^{*}$, 久保 俊 輔*5 \\ Shin-ichi AKABAYASHI, Jun SAKAGUCHI, Atsumi HOSONO, \\ Hideki SATO and Shunsuke KUBO
}

\begin{abstract}
The distribution of indoor airflow velocity by cross ventilation is influenced by the regional climate conditions, and the location as well as the shape of the building. In this study, $\mathrm{CVDHI}_{\mathrm{B}}, \mathrm{CVDHI}_{\mathrm{p}}$ and $\mathrm{CVDHI}_{\mathrm{T}}$ of $\mathrm{Cross}_{\text {Ventilation Degree }}$ Hours of Inside Area (CVDHI) are proposed. The CVDHI values of 2 cases to change the number and position of openings at 2 cities (Tokyo and Niigata) in Japan are calculated for the AIJ detached house model.

The results are as follows;

(1) The ratio of averaged $\mathrm{CVDHI}_{\mathrm{p}}$ and $\mathrm{CVDHI}_{\mathrm{B}}$ values is about 1:20 in Tokyo and Niigata.

(2) The CVDHI values increases when an opening is placed on an opposite wall in a straight line, and placed at the corner of the room.
\end{abstract}

Keywords: Cross ventilation, Cross ventilation performance, SET*, Cross Ventilation Degree Hours of Inside Area 通風，通風性能，SE T*，室内通風デグリアワー

\section{1.はじめに}

通風性能は、地域による上空風速や気温等の気象条件、建蔽 率などの建物の周囲状況、建物の形状・空開口部の大きさや配 置等に大きく影響を受け、定量的に評価することが困難であ

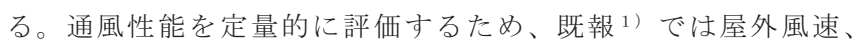
気温等の屋外気象条件と温熱環境評価尺度（SET*）の関係を 解析し、通風時の可感気流による地域の相異を通風デグリア ワー（本稿では名称を屋外通風デグリアワー：Cross V e n t i lation Degree Hours of Outside Area： CVDHO とする)によ り評価する方法を提案した。既報の C V D H O による通風性能評価 手法では、屋外の上空風速や気温等の気象条件の通風性能の 評価をすることが可能であり、例えば北海道や東京の気象条 件下の通風性能を比較することが出来る。通風は建物形状や 空開口部の大きさ及び配置に影響が高く、既報で提案した C V D H O ではこれらの影響を評価することは出来ない。

本稿では、既報 ${ }^{1)}$ で提案した CVDHO を拡張し、室内の気流分 布に着目した室内通風デグリアワー（Cross Ventilation Degree Hours of Inside Area：CVDHI）を新たに提案し、戸建
住宅を対象にCVDHI を用いた解析を行う。さらに、CVDHI で建 物の開口部の配置や通気輪道の通風性状を確認寸るため、東 京、新潟における戸建 2 階建住宅の解析を行い、CVDH I による 通風性能評価についてその妥当性を検討する。

\section{2. 室内における通風性能評価指標}

表 1 に通風性能評価指標の概念を示す。

2.1 屋外通風デグリアワーの定義 (Cross Ventilation Degree Hours of Outside Area: CVDHO)

図 1 に半閉鎖空間において人体に影響を及ぼす外的要因を 示す。屋外における通風の体感温度低減効果を評価するため、 人体に直接日射の影響を受けない空間を想定し、人体の上方 には仮想の屋根（完全黒体：長、短波長吸収率＝1）のある半閉 鎖空間の解析をする。人体周囲には壁は無いと想定し、人体は 外部風速の影響を直接受けるものとする。放射熱は、屋根面、 地面の形態係数をそれぞれ 0.5 として算出する。図 2 に C VDHO の算出方法の概要を示す。気温、湿度、気流速度注 1 )、日射量

\footnotetext{
*1 新潟大学大学院自然科学研究科 教授.工博

*2 県立新潟女子短期大学生活科学科 准教授・博士 (工学)

*3 新潟大学大学院自然科学研究科 大学院生

*4 新潟大学大学院自然科学研究科 大学院生 $\cdot$ 修士(工学) (三建設備工業(陎)

*5 前田建設工業(侏) 修士 (工学)
}

Prof., Division of Science and Technology, Graduate of Niigata Univ., Dr. Eng. Assoc. Prof., Dept. of Human Life and Environmental Science, Niigata Woman's College, Dr. Eng.

Graduate Student, Division of Science and Technology, Graduate School of Niigata Univ. Graduate Student, Division of Science and Technology, Graduate School of Niigata Univ., M. Eng.

(Sanken Setsubi Kogyo Co.)

Maeda Corporation, M. Eng. 
等の気象データより、気流速度が $0.3 \mathrm{~m} / \mathrm{s}$ の場合 $(\mathrm{SET} *(1))$ と気 流速度がある場合 (SET* (2)) の 2 種類のSET*を算出し、気流に より SET*が $26^{\circ} \mathrm{C}$ 以下に入る時の両者の温度差に時間を乗じて積 算し CVDHO を算出する。CVDHO はそれぞれの地域において、SET* が $26{ }^{\circ} \mathrm{C}$ を超えている時間に気流のみの影響により人の体感温 度をどの程度低下させるかを示寸指標である。CVDH O の值によ りそれぞれの地域が持っている気流による体感温度低下のポ テンシャルを評価することができる。CVDHO の詳細は既報 ${ }^{1)} を$ 参照。

\section{表 1 通風性能評価指標の概念}

(1) 屋外通風デグリアワー

(CVDHO: Cross Ventilation Degree Hours of Outside Area)

屋外風速に着目し、人体が屋外気流条件と屋外気象条件(温湿度、 日射等)から受ける影響の地域の相異を温熱環境評価尺度 $(\mathrm{SET}$ *)に より評価。

(2) 室内通風デグリアワー

(CVDHI: Cross Ventilation Degree Hours of Inside Area)

室内気流分布に着目し、人体が室内において地域条件、立地条件、 建物条件から受ける影響を温熱環境評価尺度 $\left(\mathrm{SET}^{*}\right)$ によ評価。

·地域条件(地域の気象条件: 風向·風速·外気温·湿度·日射量等)

·立地条件 (建物周囲の条件: 建蔽率の変化等)

建物条件(建物の性能条件:形状·平面·開口等、シェルタ一性能等)

\section{.... CVDHIの分類}

$\mathrm{CVDHI}_{\mathrm{p}}$ : 室内気流速度による体感温度低下の効果

$\mathrm{CVDHI}_{\mathrm{B}}$ : 通風を行い外気を導入することによる室温低下の効果

$\mathrm{CVDHI}_{\mathrm{T}}: \mathrm{CVDHI}_{\mathrm{P}} \subset \mathrm{CVDHI}_{\mathrm{B}}$ の合計

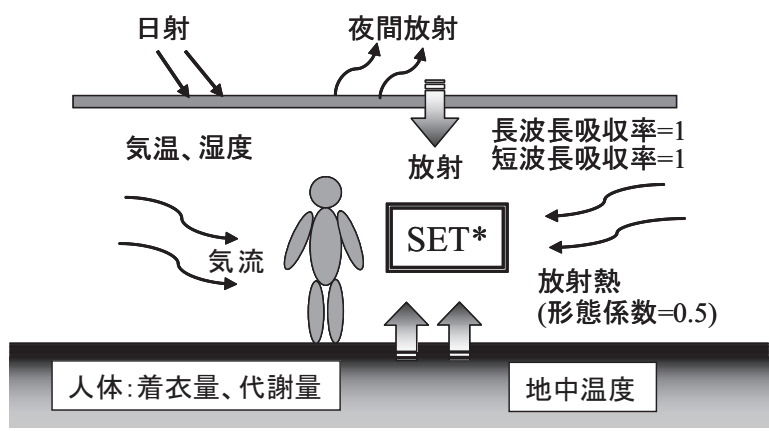

図 1 半閉鎖空間において人体に影響を及ぼす外的要因

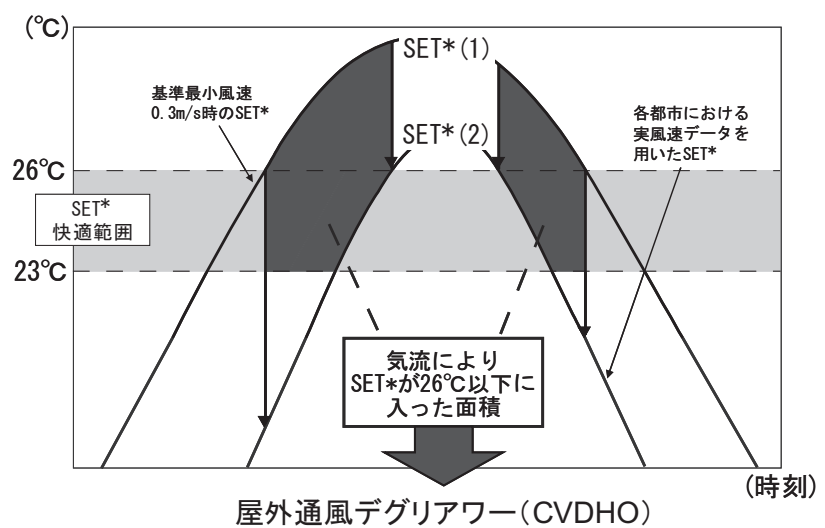

図 2 屋外通風デグリアワー ( C V D H O ) の算出方法の概要

\section{2 室内における通風性能評価指標}

（1）室内通風デグリアワーの定義 (Cross Ventilation Degree Hours of Inside Area: CVDHI)

図 3 にCVDH I で対象とする通風時の人体に影響を及ぼす外的 要因を示す。CVDHO は、屋外の気流速度による体感温度低下の ポテンシャルを表しているが、建物を考慮していないため、 C V D H O を用いて空開口部の大きさや配置等と通風性能の関係を 明らかにすることは出来ない。このため、本稿では室内気流性 状をC F D を用いて解析し、室内に滞在する人体の通風による体 感温度等の低下効果の評価手法を提案する。図 4 に室内通風 デグリアワー（CVDHI）の算出方法の概要を、図 5 にCVDHI の 解析フローを示す。最初に空閉鎖時（換気回数 0.5 回/h) の S E T* (1)の時間変化を計算する。次に SET* (1)において快適範囲 の上限である SET*が $26{ }^{\circ} \mathrm{C}$ を超えている時刻を対象に、空開放 時の実風速データによる室内気流速度と実換気回数注2)を与え た SET* (3)を算出し、SET* (3)が $26{ }^{\circ} \mathrm{C}$ を下回る範囲を抽出する。 快適範囲の下限值の S E T* $23{ }^{\circ} \mathrm{C}$ とて、実換気回数を与え、

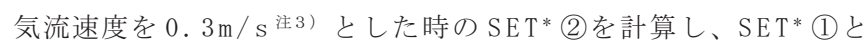
S E T* (2) との差を非暖房期間の非就寝時で積算した值を C V D H I と定義する。また、SET* (2) と S E T* (3) との差を非暖房期間の非 就寝時で積算した值を $\mathrm{CVDHI}_{\mathrm{P}}$ と定義する。CVDHI $\mathrm{B}$ と CVDHI 合計した值を CVDHI と定義する。

定義より、CVDH I は日射等の影響を受ける室内において、通 風により室内の熱を屋外に排出する排熱効果を示し、CVDH I 通風によって生じる可感気流による体感温度低下の効果を示 寸指標となる注 4 )。

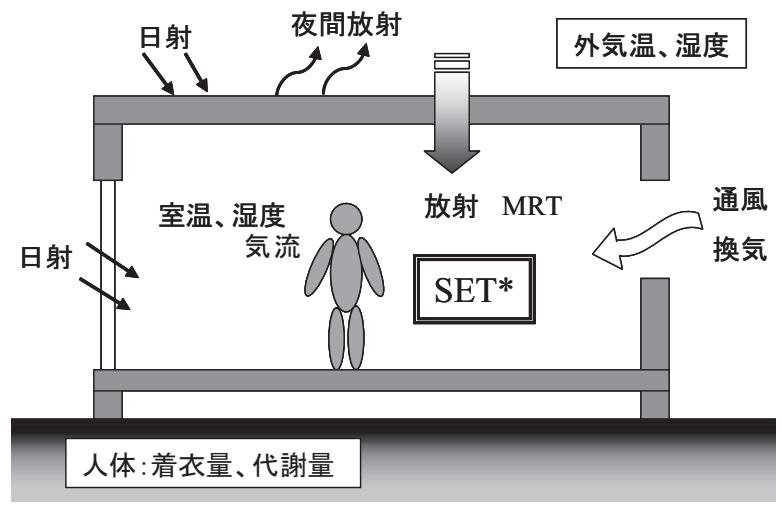

図 3 室内において人体に影響を及ぼす外的要因

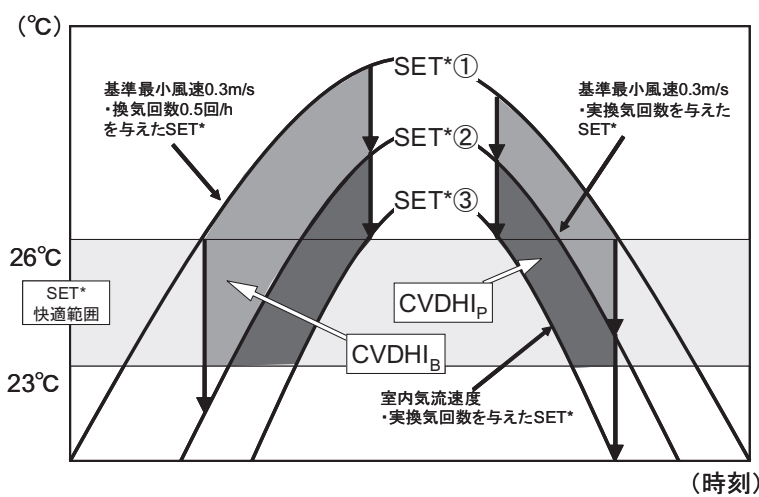

図 4 室内通風デグリアワー ( C V D H I ) の算出方法の概要 


\section{（2）解析方法}

住宅等の通風性能を定量的に評価するためには、外部風に よる室内の気流性状の時間変化を数值流体解析（CF D ）等を用 いて明らかにする必要がある。本稿では標準 $\mathrm{k}-\varepsilon$ モデルを用 いた C F D 解析により通風時の室内気流分布を計算する。CF D 解 析は計算負荷が大きいため、気象データを用いた非暖房期間 の非定常非等温シミュレーションを行うことは困難である。 そこで本稿では、対象モデルの 16 風向の室内風速比分布を $\mathrm{CF} D$ 解析 (等温解析注5) ) で算出し、室内風速比と地域の風向、風 速より室内の気流分布を、開口部風速と地域の風向、風速より 対象モデルの換気回数を求める。次に、日本建築学会拡張アメ ダス気象データ標準年の各地域の気温、湿度注6)、日射量注7) と 上記の換気回数から、熱負荷シミュレーションソフトTRNS Y S を使用し、SET*の算出に必要な室温、MRT、湿度を計算する。代 謝量を $1.0 \mathrm{Met}$ 、着衣量は 7 月〜 月 月 $0.5 \mathrm{c} 1$ o、12 月〜 2 月は $1.0 \mathrm{c} 10$ 、その他の期間は $0.75 \mathrm{c} 10$ と仮定し、室内の SET*を求め る。求められた要素から、CVDHI の定義に従い、CVDHI $、 \mathrm{CVDHI}_{\mathrm{B}}$ 、 CVDHI 、算出する。

\section{CVDHI の解析}

\section{1 解析条件}

図 6 に解析対象モデルを示す。対象住宅は日本建築学会標準 住宅モデルと寸る。TRNSYS の解析では計算負荷の関係から、建物

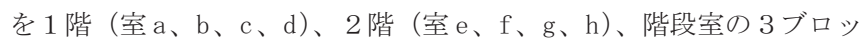
クに分け、CF D の計算結果で得られた 1 階と 2 階の換気回数を

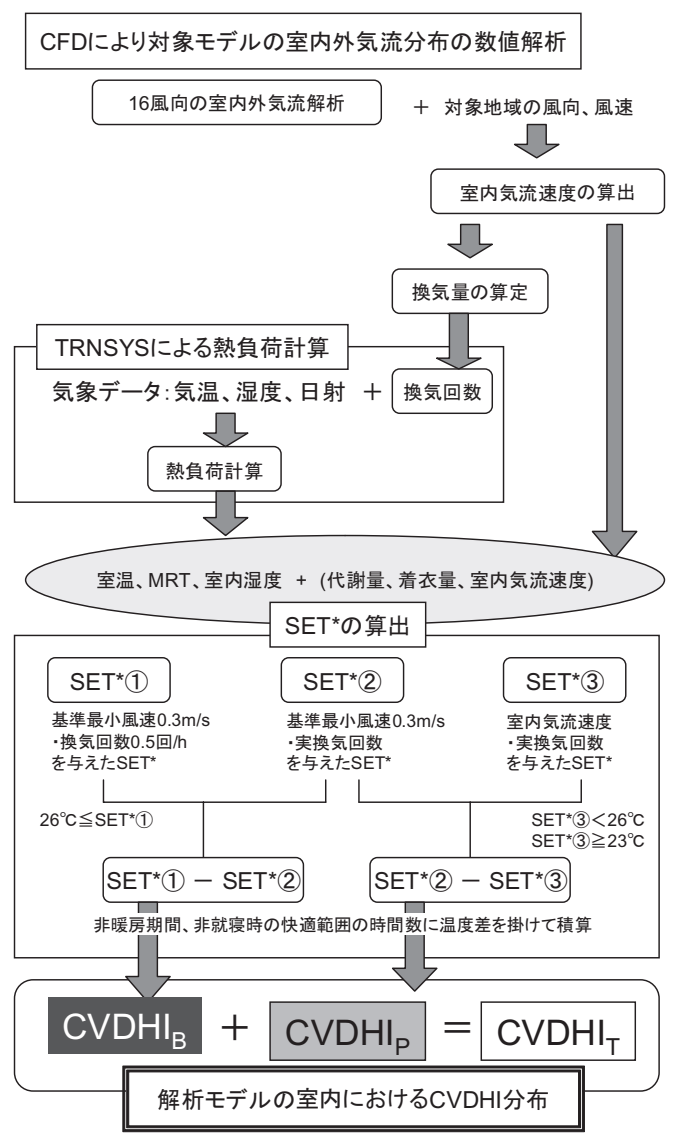

図 5 室内通風デグリアワー ( C V D H I ) の解析フロー
TRNSYS 入入力し、1 階、2 階それぞれの室温、MRT 等を算出する。 図 7 に対象地域注8) である新潟、東京の非暖房期間（新潟： 5 月 30 日〜 10 月 3 日 [126 日間]、東京: 5 月 8 日〜 10 月 13 日 [1 58 日間])、非就寝時 (午前 6 時〜 23 時) における風向別累積風 速注9）を示寸。新潟では北北東からの風の頻度が高く、東京で は南からの風の頻度が高い。表 2 に解析条件を示す。解析モデ

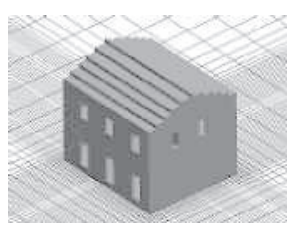

（1）モデル外観

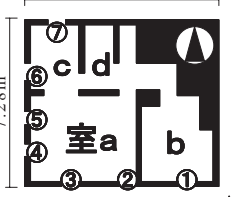

○数字は開口位置を示す

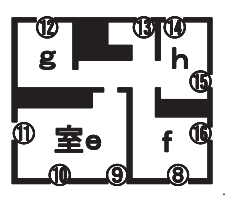

(3) $2 \mathrm{~F}$ 平面
図 6 解析対象住宅モデル

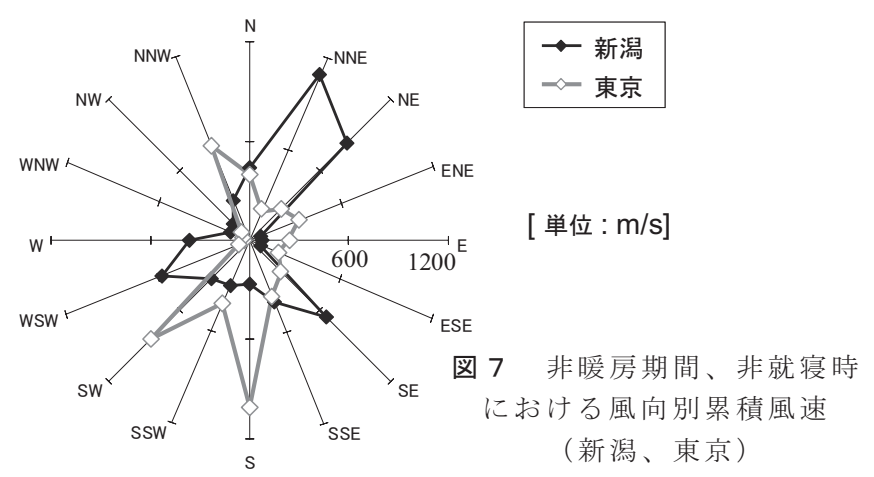

表 2 解析条件

\begin{tabular}{|c|c|}
\hline 乱流モデル & 標準k- $\varepsilon$ モデル（沉用流体解析ソフトCFD2000） \\
\hline 建蔽率 & 0\%(周囲に建物がない) \\
\hline 風向 & 16 風向 \\
\hline 数值解析領域 $(\mathrm{m})$ & $77(X) \times 70(y) \times 41(z)$ \\
\hline 室内解析メッシュ数 & $41(x) \times 34(y) \times 23(z)$ \\
\hline 延べ床面積 $\left(\mathrm{m}^{2}\right)$ & 112.8 \\
\hline 総開口面積 $\left(\mathrm{m}^{2}\right)$ & 15.0 \\
\hline 居室部分床面積 $\left(\mathrm{m}^{2}\right)$ & 69.2 \\
\hline & $\begin{array}{l}\text { 流入風速の鉛直風速分布 U(z)は、次式で与える。 } \\
U(z)=U_{s}\left(\frac{z}{z_{s}}\right)^{\alpha}\end{array}$ \\
\hline
\end{tabular}

但し、 $\mathrm{Zs}=6.5 \mathrm{~m}, \mathrm{Us}=3.0 \mathrm{~m} / \mathrm{s}, \alpha=0.25$ とする。

乱れの強さの鉛直分布 $\mathrm{I}(z)$ は、次式で与えられる。
$\mathrm{I}(z)=\frac{\sigma_{u}(z)}{U(z)}=0.1\left(\frac{z}{Z_{G}}\right)^{(-\alpha-0.05)}$

流入境界条件

$=100$

上式を参考にして、流入の $\mathrm{k}$ の鉛直分布 $\mathrm{k}(\mathrm{z})$ は、以下のように与える。 $\mathrm{k}(z)=\frac{\sigma_{u}{ }^{2}(z)+\sigma_{v}{ }^{2}(z)+\sigma_{w}{ }^{2}(z)}{2} \cong \sigma_{u}{ }^{2}(z)=(I(z) U(z))^{2}$

流入の $\varepsilon$ の鉛直分布 $\varepsilon(\mathrm{z})$ は、局所平衡を仮定して以下のように与える。

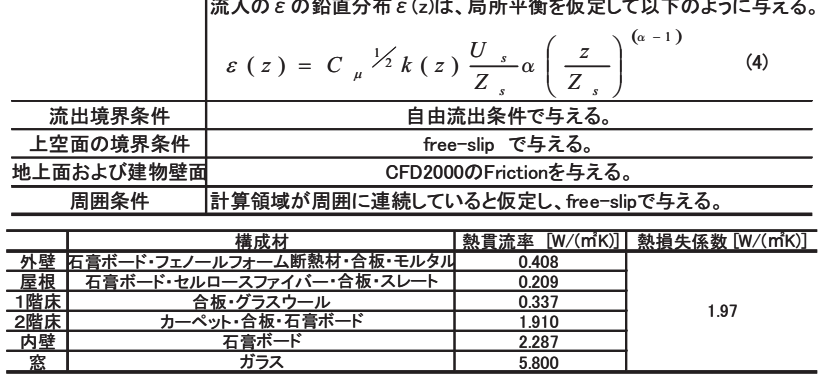

表 3 解析 c a s

\begin{tabular}{l|c|c|c}
\hline & 解析地域 & 日射条件 & 空開閉条件 \\
\hline case 1 & 新潟・東京 & 遮蔽しない & 全空開放 \\
\hline case 2-1 & \multirow{2}{*}{ 新潟 } & 直達日射を遮蔽 & \multirow{2}{*}{ 全空開放 } \\
\cline { 3 - 3 } case 3 & 全日射を遮蔽 & 空 4 箇所閉鎖 \\
\hline
\end{tabular}


ルは、次世代省エネ基準 IV 地域の断熱性能を満足する住宅で ある注10)。表 3 に解析 c a s e を示す。c a s e 2 - 1 では、建物に当 たる直達日射量を全ての時間で 0 W/ $\mathrm{m}^{2}$ とし、case 2 - 2 では、 建物に当たる直達日射量・天空日射量を全ての時間で $0 \mathrm{~W} / \mathrm{m}^{2}$ として、直達日射・天空日射の影響について検討を行う。c a s e 3 では、図 6 の平面図に示寸窓 (3) (6) (10) (16)閉鎖した場合を対 象としている。

\section{2 CVDHI の解析結果 (case 1、新潟・東京)}

図 8、9 に新潟、東京における標準住宅モデル 2 F の c a s e 1 の CVDHI 分布注11) と平均 CVDHI 注 12 を示す。新潟、東京の $\mathrm{CVDHI}_{\mathrm{p}}$ 、 $\mathrm{CVDHI}_{\mathrm{B}} 、 \mathrm{CVDHI} \mathrm{T}_{\mathrm{T}}$ 共に、室内気流が速くなる開口部周辺、間仕切 り部周辺、通気輪道上で C V D H I の大きい領域が見られる。平均 $\mathrm{CVDHI}_{\mathrm{P}}$ は平均 $\mathrm{CVDHI}_{\mathrm{B}}$ に比べ $5 \%$ 程度である。新潟は東京に比べ 相対的に CVDHI が大きく、平均 CVDHI も新潟の方が大きい。新 潟では南側に比べ北側の部屋で C V D H I B B $の$ 大き領域が広がっ ている。室 h （ $2 \mathrm{~F}$ 北東）に着目すると、新潟では間仕切り部 と空(14)を結ぶ領域で C V D H I P,

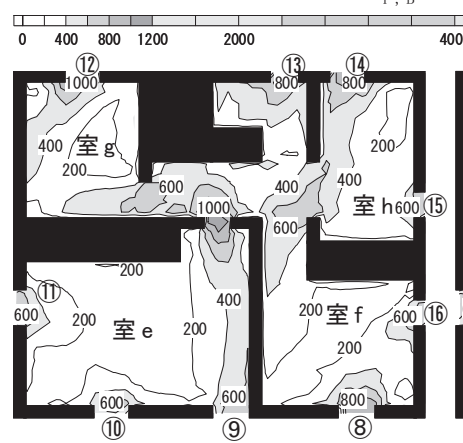

平均 $\mathrm{CVDHI} \quad 349^{\circ} \mathrm{C} \mathrm{h}$

(1) $\mathrm{CVDHI}_{\mathrm{P}}$ の分布

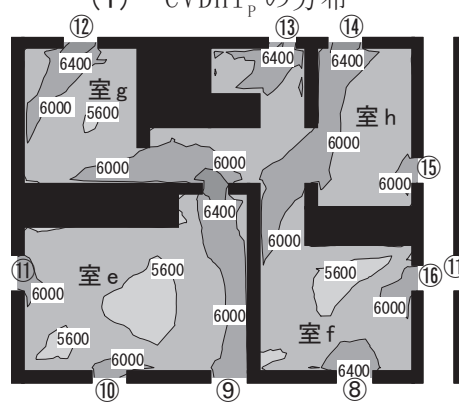

平均 $\mathrm{CVDHI}_{\mathrm{B}} \quad 5883^{\circ} \mathrm{C} \mathrm{h}$

(2) $\mathrm{CVDHI}_{\mathrm{B}}$ の分布

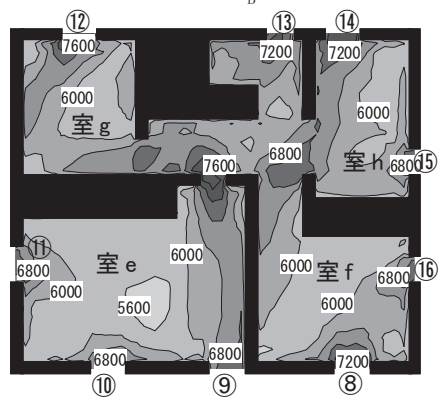

平均 CVDHI $6232^{\circ} \mathrm{C} \mathrm{h}$

(3) $\mathrm{CVDHI}_{\mathrm{T}}$ の分布

図8 case 1 の CVDHI 分布 (標準住宅モデル $2 \mathrm{~F}$ 、新潟)

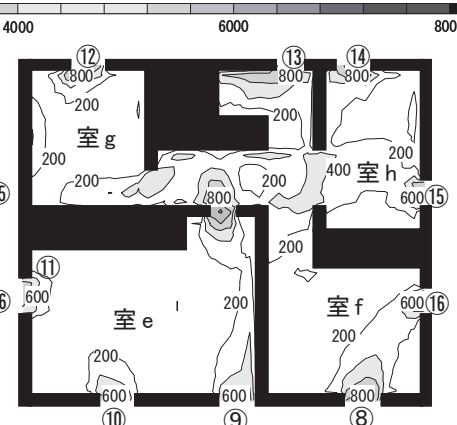

平均 $\mathrm{CVDHI}_{\mathrm{P}} \quad 213^{\circ} \mathrm{C} \mathrm{h}$

(1) $\mathrm{CVDHI}_{\mathrm{p}}$ の分布

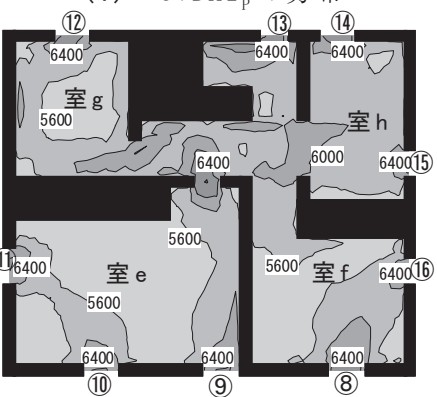

平均 $\mathrm{CVDHI}_{\mathrm{B}} \quad 5767^{\circ} \mathrm{C} \mathrm{h}$

(2) $\mathrm{CVDHI}_{\mathrm{B}}$ の分布

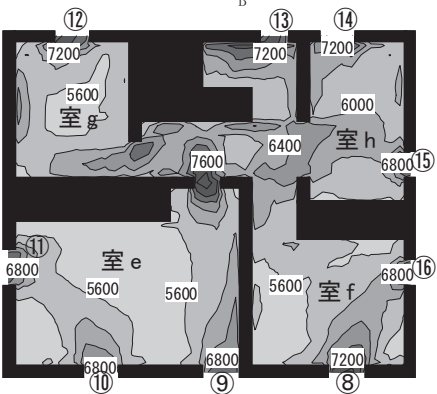

平均 $\mathrm{CVDHI}, 5980^{\circ} \mathrm{C} \mathrm{h}$

(3) $\mathrm{CVDHI}_{\mathrm{T}}$ の分布

図9 c ase 1 の CVDHI 分布 （標準住宅モデル $2 \mathrm{~F}$ 、東京）

り部と空15 を結ぶ領域で C V D H I ${ }_{\text {P, }}$ が大きくなる。図 7 に示す新 潟の風向別累積風速では、北北東風の累積風速が大きく、建物 の北北東面にある空(14)から流入し、間仕切り開口部に吹抜ける ため、両者を結ぶ領域で CVDHI ${ }_{\mathrm{P}, \mathrm{B}}$ が大きくなると考えられる。ま た、東京では南風の累積風速が大きいため、南側の部屋からの 風が室 $\mathrm{h}$ の間仕切り開口部を吹抜け直進し、空(15)から屋外一流 出するため、この領域で C V D H I ${ }_{\mathrm{P}, \mathrm{B}}$ が大きくなると考えられる。

3.3 日射遮蔽時の CVDHI の解析結果 (case 2、新潟)

図 10 に直達日射のみを遮蔽した標準住宅モデル $2 \mathrm{~F} の \mathrm{c} \mathrm{a} \mathrm{s} \mathrm{e}$ 2-1のCVDHI 分布と平均CVDHI を示す。CVDHI しないとき(図 8 (2) ) と、直達日射のみ遮蔽した c a s e 2-1の （図 $10(2)$ ) を比較すると、平均 CVDHI $\mathrm{B}_{\mathrm{B}}$ の值が半分以下となる。 一方、CVDHI $($ 図 8 （1），図 10 (1)) では 2 割程度の減少にとど まる。直達日射の有無により CVDHI ${ }_{\mathrm{B}}$ に相違を生じた理由は、直 達日射によって室温、MRT、室内の SET*が上昇したためである が、このことから C V D H I B の定義である「通風により室内の熱 を屋外に排出する排熱効果を表す指標」は、正しく評価出来て

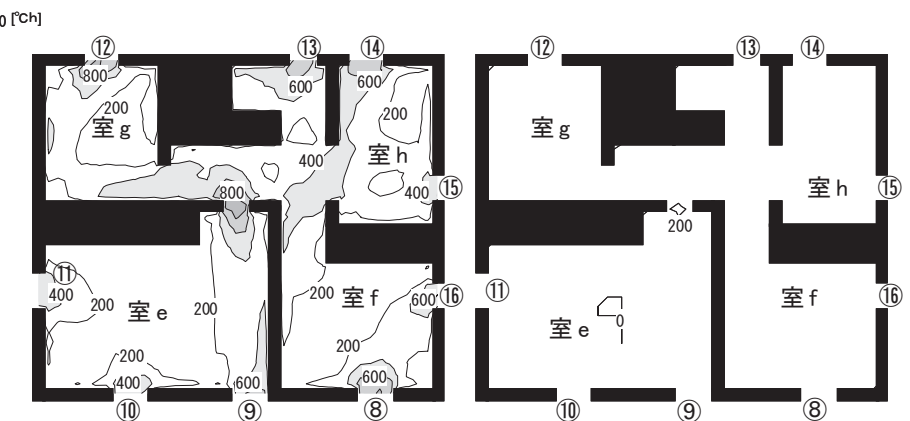

平均 $\mathrm{CVDHI}_{\mathrm{P}} 274^{\circ} \mathrm{C} \mathrm{h}$

(1) $\mathrm{CVDHI}_{\mathrm{P}}$ の分布

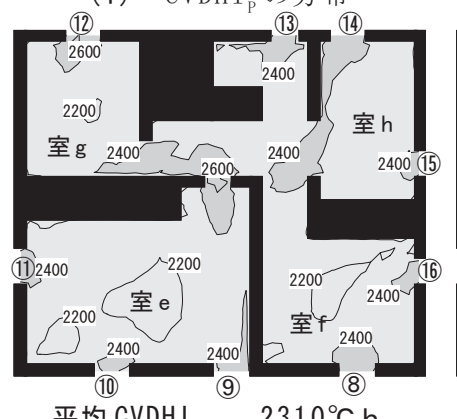

平均 $\mathrm{CVDHI}_{\mathrm{B}} \quad 2310^{\circ} \mathrm{C} \mathrm{h}$

(2) $\mathrm{CVDHI}_{\mathrm{B}}$ の分布

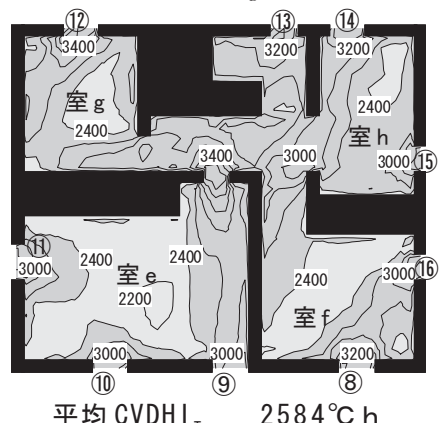

(3) $\mathrm{CVDHI}_{\mathrm{T}}$ の分布

図 10 case $2-1$ の CVDHI 分布 (標準住宅モデル 2 F、新潟)
平均 $\mathrm{CVDHI}_{\mathrm{p}} \quad 47^{\circ} \mathrm{C} \mathrm{h}$

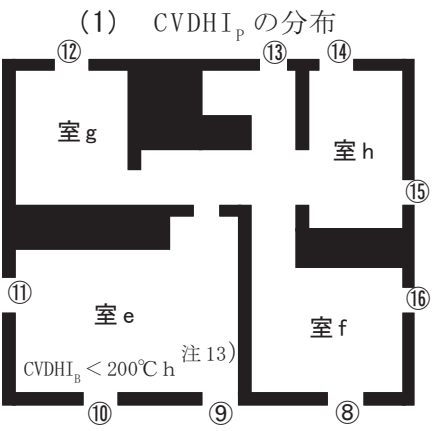

平均 $\mathrm{CVDHI}_{\mathrm{B}} \quad 35^{\circ} \mathrm{C} \mathrm{h}$

(2) $\mathrm{CVDHI}_{B}$ の分布

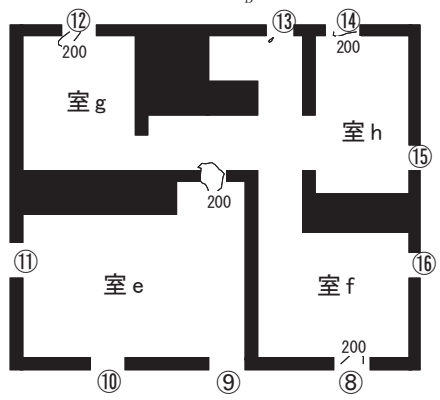

平均 $\mathrm{CVDHI}_{\mathrm{T}} \quad 82^{\circ} \mathrm{C} \mathrm{h}$

(3) $\mathrm{CVDHI}_{\mathrm{T}}$ の分布

図11 case 2-2 の CVDHI 分布 （標準住宅モデル $2 \mathrm{~F} 、$ 新潟） 
いると考えられる。同様に、直達日射の有無により、CVD H I P 差が小さいことは、CVDH I の定義である「通風によって生じる 可感気流による体感温度低下の効果を表す指標」を裏付ける ものであり、室温やM R T の低下に関係なく、可感気流による効 果のみを示していることが分かる。

図 11 に全日射を遮蔽した標準住宅モデル 2 F の c a s e 2 - 2 の C V D H I 分布と平均 C V D H I を示す。全日射を遮蔽した場合、平 均 $\mathrm{CVDHI}_{\mathrm{p}}$ は平均 $\mathrm{CVDHI}_{\mathrm{B}}$ よりも大きい值となる。しかし、CVDHI C V D H I B 共に遮蔽しないときに比べ極めて小さな值となる。これ は日射をすべて遮蔽したため室温やMRT が低下し、ほとんどの 時間で SET* (1)が $26{ }^{\circ} \mathrm{C}$ 以下になるためである。また、室温の計 算は、TRNSYSにより建物の蓄熱を考慮した解析を行っている ため、換気回数が 0.5 回 $/ \mathrm{h}$ と実換気回数を入れた室温および SET*は同じ值にはならない。このため、全日射を遮蔽した c a s e 2 - 2 の平均 CVDHI ${ }_{\mathrm{B}}$ は $35^{\circ} \mathrm{Ch}$ という值を示す。

閉鎖空の位置

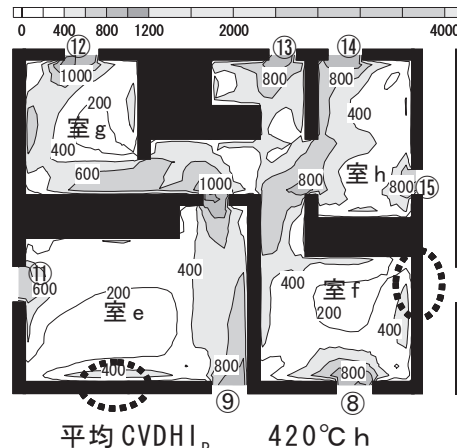

平均 $\mathrm{CVDHI}, 420^{\circ} \mathrm{C}$

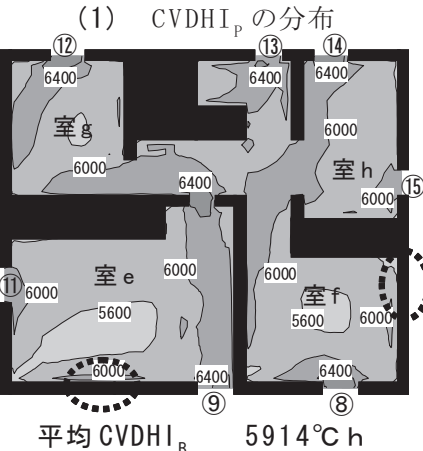

(2) $\mathrm{CVDHI}_{\mathrm{B}}$ の分布

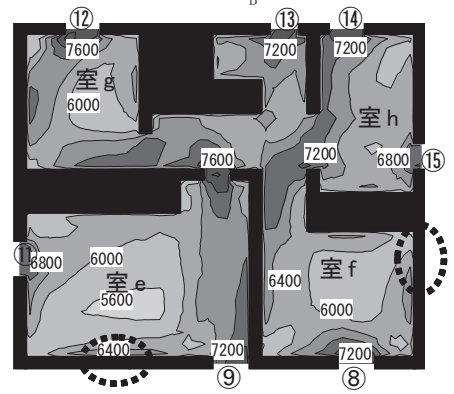

平均 $\mathrm{CVDHI}$ T $6333^{\circ} \mathrm{C} \mathrm{h}$

(3) $\mathrm{CVDHI}_{\mathrm{T}}$ の分布

図 12 case 3 の CVDHI 分布 (標準住宅モデル $2 \mathrm{~F} 、$ 新潟)

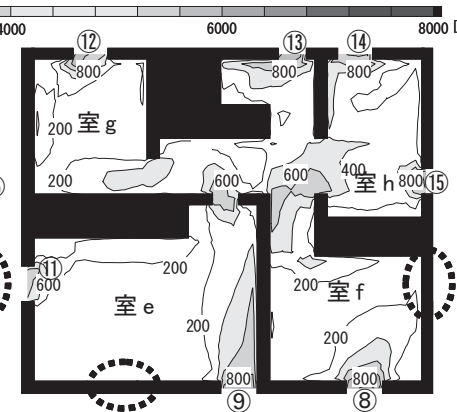

平均 $\mathrm{CVDHI}_{\mathrm{P}} \quad 266^{\circ} \mathrm{C} \mathrm{h}$

(1) $\mathrm{CVDHI}_{\mathrm{p}}$ の分布

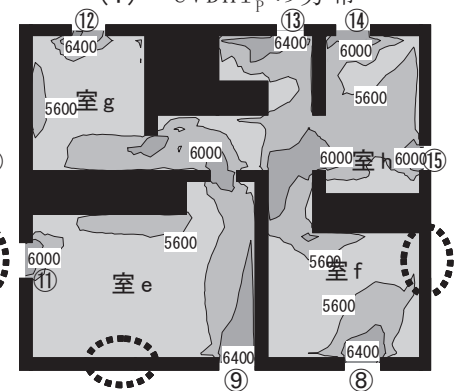

平均 CVDHI ${ }_{\mathrm{B}} \quad 5646^{\circ} \mathrm{C} \mathrm{h}$

(2) $\mathrm{CVDHI}_{\mathrm{B}}$ の分布

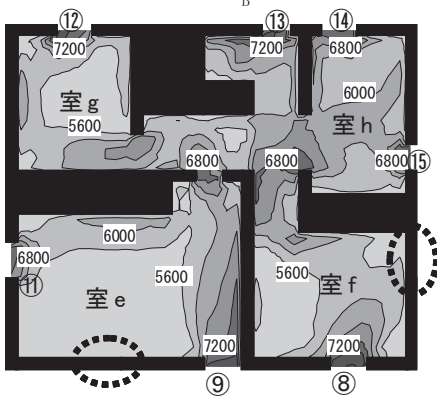

平均 $\mathrm{CVDHI}_{\mathrm{T}} \quad 5912^{\circ} \mathrm{C} \mathrm{h}$

(3) $\mathrm{CVDHI}_{\mathrm{T}}$ の分布

図 13 case 3 の CVDHI 分布 （標準住宅モデル 2 F、東京）
3.4 開口条件を変化させた場合の CVDHI の解析結果（case 3、 新潟 · 東京)

図 $12 、 13$ に新潟、東京において空を 4 箇所閉鎖した標準住宅 モデル $2 \mathrm{~F}$ の case 3 の CVDHI 分布と平均 CVDHIを示す。新潟、 東京共にすべての空を開放した case 1（図8（1），図９（1））と 比較して、空を部分的に閉鎖した c a s e 3 (図 12 (1), 図 13 (1)) の方が平均 CVDH I 室内気流速が増加し、可感気流による体感温度の低下が増加し たと考えられる。新潟の平均 CVDHI は c ase 1 と比較して case 3 の方が大きい。新潟の空を部分的に閉鎖したcase 3 のCVDH I の 分布 (図 12 (3) ) の室 e ( 2 F 南西) に注目寸ると、空10 を閉鎖 しているが、その周辺の領域で C V D H I が大きい。これは室 e で 循環流が発生したため、空が開放されなくてもこの領域で気流 が速くなるためであると考えられる。一方、東京でも空を閉鎖し たにも関わらず、平均 CVDHI は case 1 と比較して case 3 で大き な減少はみられない。空を閉鎖しても、効率よく風を取り込む ことにより通風性能が変化しないことが分かる。

\section{4. 結論}

本稿では既報 ${ }^{1}$ )で提案した、地域による通風の体感温度低 下のポテンシャルを評価できる屋外通風デグリアワー（ＣＶＤＨ０） を元に、新たに、室内気流分布を考慮し通風性能を評価寸るた めに室内通風デグリアワー（CVDH I ) を提案する。既報の C V D H O では、屋外の上空風速や気温等の気象条件の通風性能の評価 が可能であるが、建物形状や空開口部の大きさ及び配置が通 風性能に与える影響について評価することが出来ない。一方、 本報で検討している C V D H I は、室内の気流分布に着目し、通風 そのものによる室温低下と体感温度の低下効果について評価 寸ることが出来る事が確認できた。本報では戸建 2 階建住宅 を対象に解析を行い、建物の開口部の配置や通気輪道などの 通風に特徵的な室内の気流による室温及び体感温度低下効果 について C V D I を用いて検討を行った。結論をまとめると以下 の通りである。

（1） CVDHI は通風により室内の熱を屋外に排出する排熱効果を示 す C V D H I 、通風によって生じる可感気流による体感温度低下 の効果を示す CVDH I と、両者を加えた CVDH I で定義される。

（2）新潟と東京の平均 CVDHI $\mathrm{P}_{\mathrm{P}}$ は平均 $\mathrm{CVDHI}_{\mathrm{B}}$ に比較して $5 \%$ 程の 值であり、可感気流による体感温度低下効果よりも、通風に よる排熱効果の方が大幅に大きい。

（3）直達日射を遮蔽したケース ( case 2 - 1) では、平均 CVDHI B $_{\mathrm{B}}$ は 小さくなり、直達日射の影響を大きく受ける。一方、平均 $\mathrm{CVDHI}_{\mathrm{P}}$ は平均 CVDHI $\mathrm{B}_{\mathrm{B}}$ に比べて值の差は小さく、直達日射の影 響は少ない。

（4）全日射を遮蔽したケース (case 2 - 2) では、平均 CVDHI 、平 均 $\mathrm{CVDHI}$ 哄に值は小さくなる。

（5）空を 4 箇所閉鎖したモデル（case 3 ）では、case 1 に比べて、 平均 C V D H I 、 は東京では殆ど減少せず、新潟では大きくなる。 開口数を減らしても、効率よく風を取り込むことにより通風 性能が変化しないことが確認された。

（6）CVDHIを用いて地域の気象の特徴や、室内気流性状を総合的 
に考慮して通風性能評価することが可能であると考えられる。

（7）CVDHIの值は断熱性能の影響を受けると考えられる。今後、 シェルター性能を変化させた場合の検討を行う予定である。

\section{参考文献}

1）赤林伸一, 佐々木淑貴他：通風性能評価手法に関する研究, 日本建築学 会環境系論文集，No. 568,pp. 49-56,2003.6

2 ）赤林伸一・村上周三他：周辺に建物群のある独立住宅の風圧分布に関す る風洞実験および換気量予測、住宅の換気・通風に関する実験的研究 そ の 1、日本建築学会計画系論文集, No. 456, pp. 9-16, 1994.2

3）村上周三・加藤信介他：住宅の通風に関する実験的研究 その 2 風洞模 型実験による検討結果, 日本建築学会大会学術講演梗概集, 環境工学 , pp. 457-458, 1983.9

4）村上周三・加藤信介・赤林伸一他：住宅の換気・通風に関する実験的研究 その $8 \sim 10$, 日本建築学会大会学術講演梗概集, 環境工学, pp. 547$552,1990.9$

5 ）小橋史彦・倉㴊隆・大場正昭他：通風時の建物内外気流構造を目的とした LES 解析 風向 $0^{\circ}, 45^{\circ}$ の場合のシミュレーション結果とその解析, 空 気調和・衛生工学会学術講演会論文集, pp. 661-664, 2000.9

6 ）澤地孝男・清田誠良他：住宅の通風設計及び性能評価に関する実大模型 実験 その 9、その 10 , 日本建築学会大会学術講演梗概集, D-2, pp. 623$626,2001.8$

7 ) 赤坂裕・二宮秀與他 : 日本建築学会拡張アメダス気象データ, 日本建築学 会, 1999. 12

\section{注}

注 1 ）風速は人体の顔面付近の地面から $1.6 \mathrm{~m}$ の高さの値を用いている。

注 2 ) 本研究で求める 3 種類の SET*は、通風の排熱効果 ( $\mathrm{CVDHI}_{\mathrm{B}}$ で評価) と 気流による体感温度低下効果（CVDHI P $_{\mathrm{p}}$ で評価）を計算するために使用 している。SET* (3)は、通風時の SET*を求めている。SET* (2)はSET* (3) より室内気流速の影響を取り除いたSET*を計算している。SET*(2) と SET* (3)を求めるために必要な気流速度以外の室温、MRT、相対湿度は 同一の值である。SET* (1) 、通風がない状態のSET*を想定したもの である。SET* (1) は、通風が無いため、室内気流速度は無風であると仮 定し、基準最小風速の $0.3 \mathrm{~m} / \mathrm{s}$ を設定している。また、その時の換気回 数は、最低換気回数 0.5 回 $/ \mathrm{h}$ を仮定している。

注 3 ) 本研究の基準最小風速 $0.3 \mathrm{~m} / \mathrm{s}$ は、空調機などのドラフトを考慮した 值ではなく、人体周りの気流に着目し、人体発熱による熱上昇気流と 室内での軽作業を考慮し、静穏時の人体周りの気流速度を $0.3 \mathrm{~m} / \mathrm{s}$ と仮 定している。また、屋外風速が低い場合は、室内風速は $0.3 \mathrm{~m} / \mathrm{s}$ 以下と 計算される領域があるが、室内気流が $0.3 \mathrm{~m} / \mathrm{s}$ 以下の場合は、 $0.3 \mathrm{~m} / \mathrm{s}$ と し、解析を行っている。
注 4 ） CVDHI $\mathrm{B}_{\mathrm{B}}$ は、定義より日射等の影響を受ける室内において、通風により 室内の熱を屋外に排出する排熱効果を示す指標である。このため、室 内分布の無い指標のように考えられるが、本稿で提案する CVDHI 室内に分布のある指標である。CVDHI ${ }_{\mathrm{B}}$ に分布が生じる理由は、通風に より体感温度が低下した温度（SET* (3)）が $26^{\circ} \mathrm{C}$ を超えている場合で は、通風を利用しても快適範囲内に至らないため、この場合の $\mathrm{SET}^{*} の$ 低下をCVDHI に加えないためである。CVDHI は室内の各メッシュごと に時系列で SET*を算出するため、SET* (3)が $26^{\circ} \mathrm{C}$ 付近になる時間帯で は、気流速度の速い領域では SET* (3)が $26^{\circ} \mathrm{C}$ 以下、気流速度の遅い領域 では SET* (3)が $26^{\circ} \mathrm{C}$ 以上となる時間が生じるため、室内気流分布により $\operatorname{CVDHI}_{\mathrm{B}}$ に分布が生じる事になる。

注 5 ）室内外気流の CFD 解析は等温の条件で行っている。通常、室内外には 温度差が生じていると考えられるが、空を開放し、通風を行っている 場合には、極端な温度差は生じていないと仮定している。

注 6 ) 本研究では室内に湿気の発生源がなく、室内建材等の吸放湿を計算し ていない。TRNSYS では各空間ごとの水分収支を求めることができ、各 空閒の容積と換気回数から、絶対湿度を求め、室温に応じて相対湿度 を求めている。

注 7 ) 計算対象住宅の床下の温度は外気温を与えて計算をした。既報 ${ }^{1)} の$ 計算刘象（図1）の地中温度は「拡張アメダス気象データ」の地中温 度計算プログラムを使用し、普通土（熱伝導率 $1.5 \mathrm{~W} / \mathrm{mK}$ 、比熱 $3 \mathrm{MJ} / \mathrm{m}^{3} \mathrm{~K}$ ) の深さ $5 \mathrm{~cm}$ の地中温度である。

注 8 ) 全国の主要都市について解析をおこなっているが、同一の建物におい て CVDHI の值の変化について検討するため、外気温や非暖房期間の風 向別累積風速の異なる新潟と東京を対象地域とした。なお、本研究の 通風性能評価指標は、実際の通風時間を予測するものではなく、建物 の通風性能の良否を表寸指標であり、建物の設計段階において、空配 置や建物形状を評価するための指標と考えている。

注 9 ) 風向別累積風速は非暖房期間に各風向の風速を累積したものである。 非暖房期間の定義は既報 ${ }^{1)}$ と同様に、日平均気温が $18^{\circ} \mathrm{C}$ を下回る期 間を暖房期間とし、それ以外の期間を定義する。期間の初めは日平均 気温 $18^{\circ} \mathrm{C}$ を上回る期間の初めの日とし、期間の終わりは逆に 5 日間連 続 $18^{\circ} \mathrm{C}$ を下回る日の初めの日とする。なお、非就寝時は 6 時から 23 時と定義した。

注 10 ）次世代省エネルギー基準では、新潟はIII地域、東京はIV地域に区分 されている。本研究では空開口条件に着目して解析を行うため、住宅 の断熱性能については、地域区分によって断熱性能を変えることなく 解析を行っている。断熱性能が通風性能に与える影響については、次 報以降で報告する。

注 11) CVDHI 分布は床上 $0.5 \sim 1.5 \mathrm{~m}$ の平均值の分布である。

注 12）平均 CVDHI は床上 $0.5 \sim 1.5 \mathrm{~m}$ の空間(居住域) 平均の值である。

注 13) $\mathrm{CVDHI}_{\mathrm{B}}$ が $0 \sim 200^{\circ} \mathrm{Ch}$ の值で分布しているため、コンタ図が表現されない。 